\title{
Oxycodone Enhances the Effects of Metformin Therapy in Mices With Painful Diabetic Neuropathy Induced by Alloxan
}

Zahra Askari

MazUMS: Mazandaran University of Medical Sciences

Seyed Javad Boskabadi

MazUMS: Mazandaran University of Medical Sciences

Amirhossein Mahdizade

Mazandaran University of Medical Sciences

Ramin Ataee ( $\nabla$ raminataee1349@gmail.com)

Mazandaran University of Medical Sciences https://orcid.org/0000-0002-6342-0382

\section{Research Article}

Keywords: Diabetic neuropathy, stress oxidative, Oxycodone ,metformin, $\mu \&$ k-opioid receptors, Antinociceptive effect

Posted Date: February 16th, 2021

DOl: https://doi.org/10.21203/rs.3.rs-188351/v1

License: (9) This work is licensed under a Creative Commons Attribution 4.0 International License. Read Full License 


\section{Abstract \\ Background}

DN (diabetic neuropathy) is a common disorder and two thirds of diabetic patients have clinical or subclinical neuropathy. Pain in DN can be spontaneous or stimulus induced and aggravate in nights. $\mu-$ opioid receptor make weak-reply to an antinociceptive effect of opioid agonist but k-opioid receptors create antinociceptive response appropriately.

\section{Methods}

Diabetic animals were treated intraperitoneally for 3weeks in 9 groups including different doses of oxycodone and codeine with constant dose of metformin $(200 \mathrm{mg} / \mathrm{kg})$. The normal saline group was considered as a negative control group and diabetic group as positive control. After 3 weeks Hot plate and tail flic test were done and fasting blood glucose was measured. After that Animals were sacrificed and oxidative stress biomarkers including lipid peroxidation, protein carbonyl content, and glutathione content were measured in brain and liver isolated mitochondria.

\section{Conclusion}

In this study finding demonstrated that Oxycodone (high dose $8 \mathrm{mg} / \mathrm{kg}$ ) with effect on both $\mu$-opioid receptor and k-opioid receptor significantly enhances the effects of metformin therapy in mices with painful diabetic neuropathy. In addition, opioid drugs induced stress oxidative and MDA formation in brain and liver.As well as, in diabetic mices, glucose level in all drug groups significantly decreased in compared to positive diabetic group.

\section{Introduction}

Diabetic neuropathy (DN) defined peripheral nerve dysfunction caused by diabetes. Different forms of neuropathy occur in diabetic patients such as chronic inflammatory demyelinating polyneuropathy (CIDP), Autonomic neuropathy, Focal, multifocal neuropathies, Cranial neuropathy and Ulnar neuropathy. Confirmation diagnosis can be made a right clinical examination with electrophysiology, sensory, and autonomic function testing. examining pinprick, temperature, vibration perception and ankle reflexes made careful recognition of diabetic neuropathy. Probability incidence of DN depend on precondition diseases such as degree of hyperglycemia, lipid and blood pressure indexes, diabetes duration ,weight loss and depression (Boulton, Vinik et al. 2005). There is a high prevalence of DN in Asia. DN is a common disorder and two thirds of diabetic patients have clinical or subclinical neuropathy. Pain in DN can be spontaneous or stimulus induced and aggravate in nights. This syndrome is more prevalence in men. Foot care is important for DN management (Bansal, Kalita et al. 2006). 
Oxidative stress is involved in the pathogenesis of diabetic complications. Sustained hyperglycemia leads to over production of reactive oxygen species (ROS) and enhancing mitochondrial oxygen consumption, DNA damage and lipid peroxidation. Oxidative stress also reduces insulin production by impairing beta-cell function (Watkins, Hutchinson et al. 2009, Doyle and Murphy 2017).

Insulin resistance happen by activating of innate immunity and increasing age, psychological stress and smoking are important reasons that lead to activate innate immunity .Innate immune-system is the firstline defense system. Previous study demonstrated that low-grade inflammation incidence in diabetes complications.

Mononuclear phagocytes and inflammation cytokines such as CRP\&TNF involved in immunological and inflammatory processes. Two type receptors such as pattern-recognition receptors (PRRs) and toll-like receptor 4 (TLR4) play important role in recognize of inflammation and oxidative process(Wolowczuk, Verwaerde et al. 2008, Garcia, Feve et al. 2010).

In other hand, TLR4 has a key role in the innate immune response By Activating TLR4 pathways, intracellular signaling cascade are phosphorylated and leads to activation of NF-KB. NF-KB binds to the target genes that contain the pro-inflammatory genes and causes the response to hyperglycemia by increasing oxidative biomarkers and inflammatory factors. Thus in the pathogenesis of type 2 diabetes ,innate immune system might be participate (Xie, Gomes et al. 2017).

Opioid receptors and TLR4 are co-expressed in immune cells. $\mu$ opioid receptor activation can inhibit the inflammation induced by LPS. $\mu$ opioid receptor agonists also inhibited the production of ROS, NO and prostaglandin E2 (PGE2) and secretion of the pro-inflammatory cytokines and macrophage viability (Thakur, Sadanandan et al. 2020). $\mu$-opioid receptor make weak-reply to an antinociceptive effect of opioid agonist but k-opioid receptors create antinociceptive response appropriately (Nozaki, Saitoh et al. 2005).

Previous study demonstrated that, low-dose combination of two or more drugs rather than a single agent may improve antinociceptive effect in Diabetic neuropathy (DN) with fewer adverse effects(Chong and Hester 2007).

DN assayed with two models of nociception hot plate and tail flick. This pain sensitivity tests assisted to study alterations in thermal and mechanical thresholds that occur during neuropathic pain. (Bannon and Malmberg 2007).

In this study, beside of metformin therapy, administration of semi-synthetic opioid such as oxycodone and codeine with effect on opioid receptor $(\mu, \mathrm{k})$ used in order to decrease sever and medium pain due diabetic neuropathy. We suppose that multi drug therapy with different dose of metformin, oxycodone and codeine may be more effective in attenuating neuropathic pain As well as stress oxidative biomarkers (malondyaldehyde, glutathione and protein carbonyl) were assayed . 


\section{Materials And Methods}

\section{Animals}

This study was approved by Ethical Number 5277 by Committee on Animal Studies, Research Council of Mazandaran University of Medical Sciences, sari, Iran.

The animals were kept in conventional cages with free access to food and water; room temperature was kept at $23+0.5^{\circ} \mathrm{C}$ and light was controlled using a 12/12 h dark/light cycle.

\section{Experimental design}

In this study 54 Albino male mice (weight range 20-25 g) were used. The animals were randomly allocated to 9 groups of 5-7 rats as follows:

Negative control group: This group not diabetic and received Saline in all experiment course $(1 \mathrm{ml} / \mathrm{kg}$ saline)

In eight groups, diabetes was induced by a single intraperitoneal injection of $100 \mathrm{mg} / \mathrm{kg}$ alloxan. Five days later, glucose concentration, that measured with glucometer device, was used to confirm alloxaninduced diabetes. Therefore, glucose concentrations level (>200 mg/dl) was considered as diabetes induction (Fig.1).

The diabetic mice divided to eight groups as (Table.1):

- Diabetic group (as positive control)

- Oxycodone $(8 \mathrm{mg} / \mathrm{kg})$

- Codeine $(80 \mathrm{mg} / \mathrm{kg})$

- Metformin $(200 \mathrm{mg} / \mathrm{kg})$

- Oxycodone $(8 \mathrm{mg} / \mathrm{kg})+$ Codeine $(80 \mathrm{mg} / \mathrm{kg})$

- Low dose: Oxycodone $(2 \mathrm{mg} / \mathrm{kg})+$ Codeine $(20 \mathrm{mg} / \mathrm{kg})+$ Metformin $(200 \mathrm{mg} / \mathrm{kg})$

- Medium dose: Oxycodone $(4 \mathrm{mg} / \mathrm{kg})+$ Codeine $(40 \mathrm{mg} / \mathrm{kg})+$ Metformin $(200 \mathrm{mg} / \mathrm{kg})$

- High dose: Oxycodone $(8 \mathrm{mg} / \mathrm{kg})+$ Codeine $(80 \mathrm{mg} / \mathrm{kg})+$ Metformin $(200 \mathrm{mg} / \mathrm{kg})$

Alloxan and Metformin was purchased of NARVAN TEB company. As well as oxycodone hydrochloride and codeine was purchased TEMAD company. All of drugs dissolved in saline and were injected IP.

After 3 weeks, Hot plate and tail flic test were done and fasting blood glucose was measured with glucometer device. After that Animals were sacrificed and oxidative stress biomarkers including lipid peroxidation, protein carbonyl content, and glutathione content were measured in brain and liver isolated mitochondria. 
Mice were sacrificed after 24 hours of the last injections and the mice brains and livers were brought out immediately and were washed with mannitol buffer. Then pieces of brain were homogenized and mitochondria were isolated by different centrifugation $(2000 \times \mathrm{g}$ for 10 minutes; for first time) and the supernatant was separated carefully and was centrifuged at $11000 \mathrm{~g}$ for 10 minute in $4{ }^{\circ} \mathrm{C}$ and vital mitochondria were collected. Sediments of mitochondria, were dispersed in tries buffer for assessment of glutathione (GSH), protein carbonyl (PC), lipid peroxidation (LPO) experiments.

\section{Measurement of protein concentration}

Protein content was assessed by Bradford method(Jones, Hare et al. 1989).

\section{Measurement of malondialdehyde}

$0.3 \mathrm{ml}$ of thiobarbitoric acid (TBA) was added to $300 \mu \mathrm{L}$ mitochondrial fractions and was incubated in a boiling water bath for 30 minutes. After that, all the mico tubes were placed to an ice-bath, and $0.5 \mathrm{ml}$ of $\mathrm{n}$ butanol was added to each tube. Finally, samples were centrifuged at $1000 \mathrm{~g}$ for 10 minutes and and the absorption at532 nm was measured by ELISA reader. tetramethoxypropane was used as standard(Lu, Zheng et al. 2007, Boskabadi, Mokhtari-Zaer et al. 2018).

\section{Measurement of PC}

$80 \mu \mathrm{l}$ of trichloroacetic acid (TCA) was added to $0.5 \mathrm{ml}$ of mitochondrial fraction and was placed in $4{ }^{\circ} \mathrm{C}$ for 15 minutes. $300 \mu \mathrm{l}$ of 2, 4 dinitro phenyl hydrazine (DNPH) was added to each sample. All the sample tubes were incubated at room temperature for 1 hour. All of samples were washed three times with ethanol/ethyl acetate $(1 ; 1 \mathrm{v} / \mathrm{v})$, and at the end, $400 \mu \mathrm{l}$ guanidine hydrochloride was added. The proteinbound hydrazone was measured by the absorbance at $370 \mathrm{~nm}$ ELISA reader(Dalle-Donne, Rossi et al. 2003).

\section{Measurement of GSH content}

$250 \mu \mathrm{l}$ of TCA (10\%), $250 \mu \mathrm{l}$ of EDTA, $1 \mathrm{ml}$ phosphate buffer added to $0.5 \mathrm{ml}$ of mitochondrial fractions in the microtube and all of samples were centrifuged at $3500 \mathrm{~g}$ for 10 minute after that supernatant were separated and200 $\mu$ Ellman's reagent( DTNB )added to supernatant. The GSH content was measured by the absorbance at $412 \mathrm{~nm}$. Data analysis with GSH standard curve(Oliveira, Almeida et al. 2007).

\section{Fasting blood sugar assay}

Fasting blood sugar was measured with glucose rapid detect kit by glucometer device .In order to, one tail blood drop of diabetic mice was used .

\section{Hotplate test}

Heat used as a noxious stimulus in this model of acute pain. The hot plate was set to a constant temperature of $55 \pm 0.2 \cdot C$.latency time that mices first lich it's paw was recorded as the nociceptive 
response. Cut-off time was set 60 second(Tjølsen, Rosland et al. 1991).

\section{Tail flick test}

Tail flick test were done by tail flick device. A flick of the tail away from the heat source, is a flexion reflex of spinal .50V movie light focused on the mices tail .Latency time that the mice moved its tail side was recorded. Cut-off time for tail flick device that was used this research was limit 30 second. Temperature of the lab was maintained at $24 \pm 05^{\circ} \mathrm{C}$ during test time(Manning and Mayer 1995, Bannon and Malmberg 2007).

\section{Statistical Analysis}

The results were described as mean \pm SEM. Comparisons between the results of different groups were performed using one-way analysis of variance (ANOVA) with Tukey-Kramer's post-test Graph pad Prism software (version 6 ) was used to $P$ value $<0.05$ was considered significant.

\section{Results}

In this study, the effect of simultaneous oxycodone, codeine and metformin on stress oxidative biomarkers malondialdehyde (MDA), glutathione(GSH), protein carbonyl (PC) in the brain and liver, diabetic neuropathy tests (tail flick and hotplate test), glucose test and inflammation test demonstrated

\section{Comparison between the effects of different doses of oxycodone and codeine (low, medium and high doses $)+$ metformin $(200 \mathrm{mg} / \mathrm{kg})$ on oxidant-antioxidant biomarkers}

In brain, MDA content in oxycodone \&codeine (low, mead, high dose)+metformin groups significantly $(p<0.001)$ increased in compared to control group. And so, MDA content oxy \&cod (high dose)+met group significantly $(p<0.001)$ decreased in compared to three groups such as positive group, oxy \&cod(low dose and mead dose)+met groups (figure2).In liver, MDA content in oxy \&cod(mead dose)+met group significantly $(\mathrm{p}<0.01)$ increased in compared to negative control and positive groups. And so, MDA content in groups oxy \&cod(high dose)+met significantly $(p<0.001)$ decreased in compared to oxy \&cod( mead dose)+met group (figure3).In brain ,PC content in oxy \&cod(mead dose)+met group significantly $(p<0.01)$ increased in compared to positive group (figure6). In liver, pc content in oxy $\& \operatorname{cod}($ mead dose $)+$ met significantly $(p<0.001)$ decreased in compared to control group, positive group and oxy \&cod(low dose)+met group(figure7).

\section{Comparison the effects of high dose of oxycodone and codeine on oxidant-antioxidant biomarkers}

In brain, MDA content in high dose of oxycodone and codeine significantly $(p<0.001)$ decreased in compared to three groups such as positive group ,oxy \&cod(low dose and mead dose)+met groups (figure2).And so, in liver, MDA content in high dose oxycodone and codeine significantly $(p<0.001)$ decreased in compared to oxy \&cod( mead dose)+met group (figure3).In liver, pc 
content in high dose of oxycodone and codeine significantly $(\mathrm{p}<0.001)$ decreased in compared to control group, positive group and oxy \&cod(low dose)+met group(figure7).

\section{The effect of high dose oxycodone on oxidant-antioxidant biomarkers}

In brain, MDA content in oxycodone (high dose) significantly $(p<0.001)$ decreased in compared to three groups such as positive group ,oxy \&cod(low dose and mead dose)+met groups (figure2). In liver, MDA content in high dose oxycodone significantly $(p<0.001)$ decreased in compared to oxy \&cod( mead dose)+met group (figure3).In brain, GSH content in high dose of oxycodone significantly $(p<0.05)$ increased compared to control group. So, GSH content in positive group significantly $(p<0.05)$ decreased in compared to control group. (figure4). In liver tissue, GSH content not significant any groups(figure5). In brain, PC content in high dose of oxycodone significantly $(\mathrm{p}<0.001)$ decreased in compared to oxy \&cod(mead dose)+met group(figure6).In liver, pc content in high dose of oxycodone significantly $(p<0.001)$ decreased in compared to control group, positive group and oxy \&cod(low dose)+met group(figure7).

\section{The effect of high dose codeine on oxidant-antioxidant biomarkers}

In brain, MDA content in codeine(high dose) significantly $(p<0.001)$ decreased in compared to three groups such as positive group ,oxy \&cod(low dose and mead dose)+met groups (figure1).

\section{The effect of metformin $(200 \mathrm{mg} / \mathrm{kg})$, on oxidant-antioxidant biomarkers}

In brain, MDA content in metformin $(200 \mathrm{mg} / \mathrm{kg})$ significantly $(\mathrm{p}<0.001)$ decreased in compared to three groups such as positive group ,oxy \&cod(low dose and mead dose)+met groups (figure2).In liver, MDA content in metformin $(200 \mathrm{mg} / \mathrm{kg})$ significantly $(\mathrm{p}<0.001)$ decreased in compared to oxy \&cod( mead dose)+met group (figure3). In brain, protein carbonyl content in metformin(200mg/kg)group significantly $(p<0.01)$ decreased in compared to control group. And so,

metformin $(200 \mathrm{mg} / \mathrm{kg})$ significantly $(\mathrm{p}<0.001)$ decreased in compared to oxy \&cod(mead dose)+met group (figure6). In liver, pc content in metformin $(200 \mathrm{mg} / \mathrm{kg})$ significantly $(\mathrm{p}<0.001)$ decreased in compared to control group, positive group and oxy \&cod(low dose)+met group(figure7).

\section{The effect of diabetic neuropathy tests (tail flick and hotplate test) on the nociceptive response}

In hot plate test ,latency time that mice lick it's paw significantly increased $(p<0.05)$ in high dose of oxycodone and metformin $(200 \mathrm{mg} / \mathrm{kg}$ ) in compared to positive group and oxy \&cod(low dose) +met group(figure8). Tail flick test, latency time that mice move side it's tail in oxy \&cod(mead dose)+met significantly $(p<0.05)$ decreased in compared to oxycodone(high dose,8mg/kg) and control group(figure9).

\section{The effect of different doses of oxycodone ,codeine and metformin on fasting blood glucose level:}

Fasting blood glucose level in positive (diabetic) group significantly $(\mathrm{p}<0.001)$ increased in compared to control group .In all drug groups, fasting blood glucose significantly $(p<0.001)$ decreased in compared to 
positive(diabetic)group(figure10).

\section{Discussion}

In this study, the effects of oxycodone, codeine and metformin therapy in mices with painful diabetic neuropathy induced by alloxan, was investigated. Alloxan induce toxic effect on pancreatic beta cells. This toxic effect such as oxidation sulphydryl group(SH) on the pancreatic cell membrane, induce stress oxidative, inhibition essential enzyme(Jones, Hare et al. 1989).

In this research, MDA content in brain significantly $(p<0.001)$ increased in positive(diabetic)group in compared to negative control group. In brain, glutathione content in positive(diabetic)group significantly $(p<0.05)$ decreased in compared to negative control group. This finding showed that alloxan passed blood brain barrier and induce stress oxidative. So diabetic disease during assortment of biological occurrences induced stress oxidative.

Opiate drug induced stress oxidative and increased lipid peroxidation and decreased GSH level (Özmen, Nazıroğlu et al. 2007). In this study, finding showed that in brain MDA level increase in oxy \&cod(low dose , mead dose $)+$ met groups significantly $(p<0.001)$ increased in compared to control group. However in other drug group, particularly oxy \&cod(high dose) + met group MDA content in brain significantly $(\mathrm{p}<$ 0.001) decreased in compared to oxy \&cod(low dose) + met and oxy \&cod(mead dose) + met groups(Fig. 1(. This finding demonstrated that in high dose of oxycodone and codeine therapy, antioxidant defense was improved in brain and MDA content was decreased. previous study showed that morphine and opioid derivation induced stress oxidative and stimulate ros formation and queer antioxidant enzyme that triggered extreme adverse effect(Skrabalova, Drastichova et al. 2013). Biogenesis of several endogenous opioid peptides are derived from different precursor proteins such as prodynorphin (PDYN) and proenkephalin( PENK). PENK-derived peptides create short lasting antinociceptive effect because of sensitivity to proteolytic process(Przewłocki and Przewłocka 2001).

Morphine and semi-synthetic opioid such as oxycodone and codeine, with effect on opioid receptor $(\mu, k)$ frequently use in decrease sever and medium pain for instance pain due diabetic neuropathy.

$\mu, \kappa$, and $\delta$ opioid receptor subtypes and TLR4 have been localized on immune cells. In painful diabetic neuropathy rat models, TLR4 levels were up regulated. TLR4 activation stimulate inflammatory responses in the body. $\mu$ opioid receptor activation attenuates the increase in inflammatory cytokines. $\delta$ opioid receptor (DOR) activation inhibits the production of NO and increases superoxide dismutase (SOD) and GSH-Px activity(Zhang, Yang et al. 2020).

Induction stress oxidative interact ATP production in mitochondria and ATP perform vital role in cell signaling, metabolism, cell proliferation, inflammation and immune response. After morphine activate $\mu$ opioid receptor, some of biological events cause intracellular and mitochondrial calcium (Ca2+) increased .calcium plays a key role in increasing ROS and other free radicals consequently cytotoxicity induced (Cunha-Oliveira, Cristina Rego et al. 2013, Vašková, Kočan et al. 2016). 
Different internal and external reasons effects on qeering antioxidant enzyme in opioid consumptions such as dose, duration of treatment, drug interaction and deficiency of drug biotransformation in different disease (Hsiao, Chang et al. 2009).

Previous research demonstrated that NADPH has important role in morphine metabolism. So, NADPH is essential co-factor for antioxidant enzyme GSH reductase and NO synthase(NOS). Glutathione reductase regenerative GSSG to reduced GSH. After producing NO by NOS, during rapid reaction NO with super oxide radicals ( $02 \cdot-$ ) ,produce peroxynitrite. reducing agent Pterin, is a potent scavenger of $02 \cdot-$, thus if prevent NO production by NOS inhibition, 02 -- releases to form of $\mathrm{H} 2 \mathrm{O} 2$ instead 02 -- react to NO. Increasing L-arginine concentration, reduced morphine anti-nociceptive efficacy. Thus, NOS plays important role on the biotransformation, efficacy of morphine and release free radicals (Hsiao, Chang et al. 2009). In hot plate test, latency time that mice licking it's hind paw in oxycodone(high dose $) \&$ metformin $(200 \mathrm{mg} / \mathrm{kg})$ groups significantly $(p<0.05)$ increased in compared to positive(diabetic)group. previous study demonstrated that hot plate test is valid method for neuropathy studies. In diabetic mice, both $\mu$-opioid receptor and $\mathrm{k}$-opioid receptor mediate antinociceptive effect of oxycodone (high dose) because in previous study demonstrated the pain relieving effects of oxycodone (high dose )in diabetic mices frustrate by k-opioid receptor antagonist (Nozaki, Saitoh et al. 2005). In diabetes mellitus, Metformin attenuate neuropathic pain through adenosine monophosphate-activated kinase (AMPK) pathway also by activating this pathway enact anti-oxidative effects and create protective effect ( $\mathrm{Ma}, \mathrm{Yu}$ et al. 2015). Tail flick test in this study, latency time in oxycodone(high dose)significantly( $\mathrm{p}$ $<0.05$ ) increased in compared to oxy \&cod(mead dose) + met. Latency time in oxycodone(high dose $8 \mathrm{mg} / \mathrm{kg}$ ) resemble to negative control group. Tail flick latency depend on tail temperature. If their tail be cooler, tail flick latency extend more (King, Joynes et al. 1997). In this study, fasting blood sugar in all drug groups significantly $(p<0.001)$ decreased in compared to positive diabetic group. Previous study demonstrated that in diabetic mices, glucose make antagonist effect on the opiate receptor (Simon and Dewey 1981).as well as, in diabetic rats hypothalamic B-endorphin production decreased in comparison non diabetic rats consequently hot plate latency in diabetic mice be shortened(Forman, Estilow et al. 1986).

pain relifing peptide such as serotonin, dopamine, glucocorticoids, substance $P$, and somatostatin have important role in pain perception same as hypothalamic p-endorphin(Locatelli, Petraglia et al. 1986).

In brain, endorphin play major role in pain reliefing and may regulate glucose hemostasis process. when insulin secretion reduced in diabetic rats, as well as decreased B-endorphin synthesis in hypothalamus and effect on morphine efficacy(Locatelli, Petraglia et al. 1986).

In conclusion, in this study finding demonstrated that opioid drugs induced stress oxidative and MDA formation in brain and liver .As well as, Oxycodone(high dose $8 \mathrm{mg} / \mathrm{kg}$ ) with effect on both $\mu$-opioid receptor and k-opioid receptor significantly enhances the effects of metformin therapy in mices with painful diabetic neuropathy .Even though, in diabetic mices, glucose make antagonist effect on the opiate 
receptor, anyway glucose level in all drug groups significantly decreased in compared to positive diabetic group.

\section{Declarations}

\section{Conflict of interest statement}

The authors declare no conflicts of interest .

\section{Acknowledgments}

This project was financially supported by a grant from the Research Council of Mazandaran University of Medical Sciences, Sari Iran.

\section{References}

1. Bannon, A. W. and A. B. Malmberg (2007). "Models of nociception: hot-plate, tail-flick, and formalin tests in rodents." Current protocols in neuroscience 41(1): 8.9. 1-8.9. 16.

2. Bansal, V., J. Kalita and U. Misra (2006). "Diabetic neuropathy." Postgraduate medical journal 82(964): 95-100.

3. Boskabadi, J., A. Mokhtari-Zaer, A. Abareshi, M. R. Khazdair, B. Emami, N. Mohammadian Roshan, M. Hosseini and M. H. Boskabady (2018). "The effect of captopril on lipopolysaccharide-induced lung inflammation." Experimental lung research 44(4-5): 191-200.

4. Boulton, A. J., A. I. Vinik, J. C. Arezzo, V. Bril, E. L. Feldman, R. Freeman, R. A. Malik, R. E. Maser, J. M. Sosenko and D. Ziegler (2005). "Diabetic neuropathies: a statement by the American Diabetes Association." Diabetes care 28(4): 956-962.

5. Chong, M. S. and J. Hester (2007). "Diabetic painful neuropathy." Drugs 67(4): 569-585.

6. Cunha-Oliveira, T., A. Cristina Rego and C. R Oliveira (2013). "Oxidative stress and drugs of abuse: an update." Mini-Reviews in Organic Chemistry_ 10(4): 321-334.

7. Dalle-Donne, I., R. Rossi, D. Giustarini, A. Milzani and R. Colombo (2003). "Protein carbonyl groups as biomarkers of oxidative stress." Clinica chimica acta 329(1-2): 23-38.

8. Doyle, H. H. and A. Z. Murphy (2017). "Sex differences in innate immunity and its impact on opioid pharmacology." Journal of neuroscience research 95(1-2): 487-499.

9. Forman, L., S. Estilow, M. Lewis and P. Vasilenko (1986). "Streptozocin diabetes alters immunoreactive $\beta$-endorphin levels and pain perception after 8 wk in female rats." Diabetes 35(12): 1309-1313.

10. Garcia, C., B. Feve, P. Ferre, S. Halimi, H. Baizri, L. Bordier, G. Guiu, O. Dupuy, B. Bauduceau and H. Mayaudon (2010). "Diabetes and inflammation: fundamental aspects and clinical implications." 
Diabetes \& metabolism 36(5): 327-338.

11. Hsiao, P.-N., M.-C. Chang, W.-F. Cheng, C.-A. Chen, H.-W. Lin, C.-Y. Hsieh and W.-Z. Sun (2009). "Morphine induces apoptosis of human endothelial cells through nitric oxide and reactive oxygen species pathways." Toxicology. 256(1-2): 83-91.

12. Jones, C. G., J. D. Hare and S. J. Compton (1989). "Measuring plant protein with the Bradford assay." Journal of chemical ecology 15(3): 979-992.

13. King, T. E., R. L. Joynes and J. W. Grau (1997). "Tail-flick test: II. The role of supraspinal systems and avoidance learning." Behavioral neuroscience 111(4): 754.

14. Locatelli, V., F. Petraglia, N. Tirloni and E. E. Müller (1986). " $\beta$-endorphin concentrations in the hypothalamus, pituitary and plasma of streptozotocin-diabetic rats with and without insulin substitution therapy." Life sciences 38(4): 379-386.

15. Lu, J., Y.-L. Zheng, D.-M. Wu, L. Luo, D.-X. Sun and Q. Shan (2007). "Ursolic acid ameliorates cognition deficits and attenuates oxidative damage in the brain of senescent mice induced by D-galactose." Biochemical pharmacology. 74(7): 1078-1090.

16. Ma, J., H. Yu, J. Liu, Y. Chen, Q. Wang and L. Xiang (2015). "Metformin attenuates hyperalgesia and allodynia in rats with painful diabetic neuropathy induced by streptozotocin." European journal of pharmacology. 764: 599-606.

17. Manning, B. H. and D. J. Mayer (1995). "The central nucleus of the amygdala contributes to the production of morphine antinociception in the rat tail-flick test." Journal of Neuroscience 15(12): 8199-8213.

18. Nozaki, C., A. Saitoh, N. Tamura and J. Kamei (2005). "Antinociceptive effect of oxycodone in diabetic mice." European journal of pharmacology 524(1-3): 75-79.

19. Oliveira, A., J. Almeida, R. Freitas, V. Nascimento, L. Aguiar, H. Júnior, F. Fonseca, G. Viana, F. Sousa and M. Fonteles (2007). "Effects of levetiracetam in lipid peroxidation level, nitrite-nitrate formation and antioxidant enzymatic activity in mice brain after pilocarpine-induced seizures." Cellular and molecular neurobiology 27(3): 395-406.

20. Özmen, İ., M. Nazıroğlu, H. A. Alici, F. Şahin, M. Cengiz and I. Eren (2007). "Spinal morphine administration reduces the fatty acid contents in spinal cord and brain by increasing oxidative stress." Neurochemical Research 32(1): 19-25.

21. Przewłocki, R. and B. Przewłocka (2001). "Opioids in chronic pain." European journal of pharmacology. 429(1-3): 79-91.

22. Simon, G. S. and W. L. Dewey (1981). "Narcotics and diabetes. I. The effects of streptozotocininduced diabetes on the antinociceptive potency of morphine." Journal of Pharmacology and Experimental Therapeutics 218(2): 318-323.

23. Skrabalova, J., Z. Drastichova and J. Novotny (2013). "Morphine as a potential oxidative stresscausing agent." Mini-reviews in organic chemistry 10(4): 367-372.

24. Thakur, V., J. Sadanandan and M. Chattopadhyay (2020). "High-Mobility Group Box 1 Protein Signaling in Painful Diabetic Neuropathy." International journal of molecular sciences 21(3): 881. 
25. Tjølsen, A., J. H. Rosland, O.-G. Berge and K. Hole (1991). "The increasing-temperature hot-plate test: an improved test of nociception in mice and rats." Journal of pharmacological methods 25(3): 241250.

26. Vašková, J., L. Kočan and L. Vaško (2016). "Oxidative stress and opioids." Glob J Anesth 3(1): 020029.

27. Watkins, L. R., M. R. Hutchinson, K. C. Rice and S. F. Maier (2009). "The "toll" of opioid-induced glial activation: improving the clinical efficacy of opioids by targeting glia." Trends in pharmacological sciences 30(11): 581-591.

28. Wolowczuk, I., C. Verwaerde, O. Viltart, A. Delanoye, M. Delacre, B. Pot and C. Grangette (2008). "Feeding our immune system: impact on metabolism." Clinical and Developmental Immunology. 2008.

29. Xie, N., F. P. Gomes, V. Deora, K. Gregory, T. Vithanage, Z. D. Nassar, P. J. Cabot, D. Sturgess, P. N. Shaw and M.-O. Parat (2017). "Activation of $\mu$-opioid receptor and Toll-like receptor 4 by plasma from morphine-treated mice." Brain, behavior, and immunity 61: 244-258.

30. Zhang, P., M. Yang, C. Chen, L. Liu, X. Wei and S. Zeng (2020). "Toll-Like Receptor 4 (TLR4)/Opioid Receptor Pathway Crosstalk and Impact on Opioid Analgesia, Immune Function, and Gastrointestinal Motility." Frontiers in Immunology 11.

\section{Tables}


Table 1

Different groups of the study and treatment protocols.

\begin{tabular}{|c|c|c|c|}
\hline Group name & $\begin{array}{l}\text { Step } 1 \text { (Single ip } \\
\text { injection) }\end{array}$ & Step 2 (every day for three weeks) & $\begin{array}{l}\text { Animals } \\
\text { number }\end{array}$ \\
\hline $\begin{array}{l}\text { Negative } \\
\text { control group }\end{array}$ & Salin $1 \mathrm{ml} / \mathrm{kg}$ & Salin $1 \mathrm{ml} / \mathrm{kg}$ & 6 \\
\hline Diabetic group & $\begin{array}{l}\text { alloxan } \\
100 \mathrm{mg} / \mathrm{kg}\end{array}$ & Salin $1 \mathrm{ml} / \mathrm{kg}$ & 6 \\
\hline Oxycodone & $\begin{array}{l}\text { alloxan } \\
100 \mathrm{mg} / \mathrm{kg}\end{array}$ & Oxycodone $8 \mathrm{mg} / \mathrm{kg}$ & 6 \\
\hline Codeine & $\begin{array}{l}\text { alloxan } \\
100 \mathrm{mg} / \mathrm{kg}\end{array}$ & Codeine $80 \mathrm{mg} / \mathrm{kg}$ & 6 \\
\hline Metformin & $\begin{array}{l}\text { alloxan } \\
100 \mathrm{mg} / \mathrm{kg}\end{array}$ & Metformin $200 \mathrm{mg} / \mathrm{kg}$ & 6 \\
\hline $\begin{array}{l}\text { Oxycodone }+ \\
\text { Codeine }\end{array}$ & $\begin{array}{l}\text { alloxan } \\
100 \mathrm{mg} / \mathrm{kg}\end{array}$ & Oxycodone $(8 \mathrm{mg} / \mathrm{kg})+$ Codeine $(80 \mathrm{mg} / \mathrm{kg})$ & 6 \\
\hline Low dose & $\begin{array}{l}\text { alloxan } \\
100 \mathrm{mg} / \mathrm{kg}\end{array}$ & $\begin{array}{l}\text { Oxycodone }(2 \mathrm{mg} / \mathrm{kg})+\text { Codeine }(20 \mathrm{mg} / \mathrm{kg})+ \\
\text { Metformin }(200 \mathrm{mg} / \mathrm{kg})\end{array}$ & 6 \\
\hline Medium dose & $\begin{array}{l}\text { alloxan } \\
100 \mathrm{mg} / \mathrm{kg}\end{array}$ & $\begin{array}{l}\text { Oxycodone }(4 \mathrm{mg} / \mathrm{kg})+\text { Codeine }(40 \mathrm{mg} / \mathrm{kg})+ \\
\text { Metformin }(200 \mathrm{mg} / \mathrm{kg})\end{array}$ & 6 \\
\hline High dose & $\begin{array}{l}\text { alloxan } \\
100 \mathrm{mg} / \mathrm{kg}\end{array}$ & $\begin{array}{l}\text { Oxycodone }(8 \mathrm{mg} / \mathrm{kg})+\text { Codeine }(80 \mathrm{mg} / \mathrm{kg})+ \\
\text { Metformin }(200 \mathrm{mg} / \mathrm{kg})\end{array}$ & 6 \\
\hline
\end{tabular}

\section{Figures}




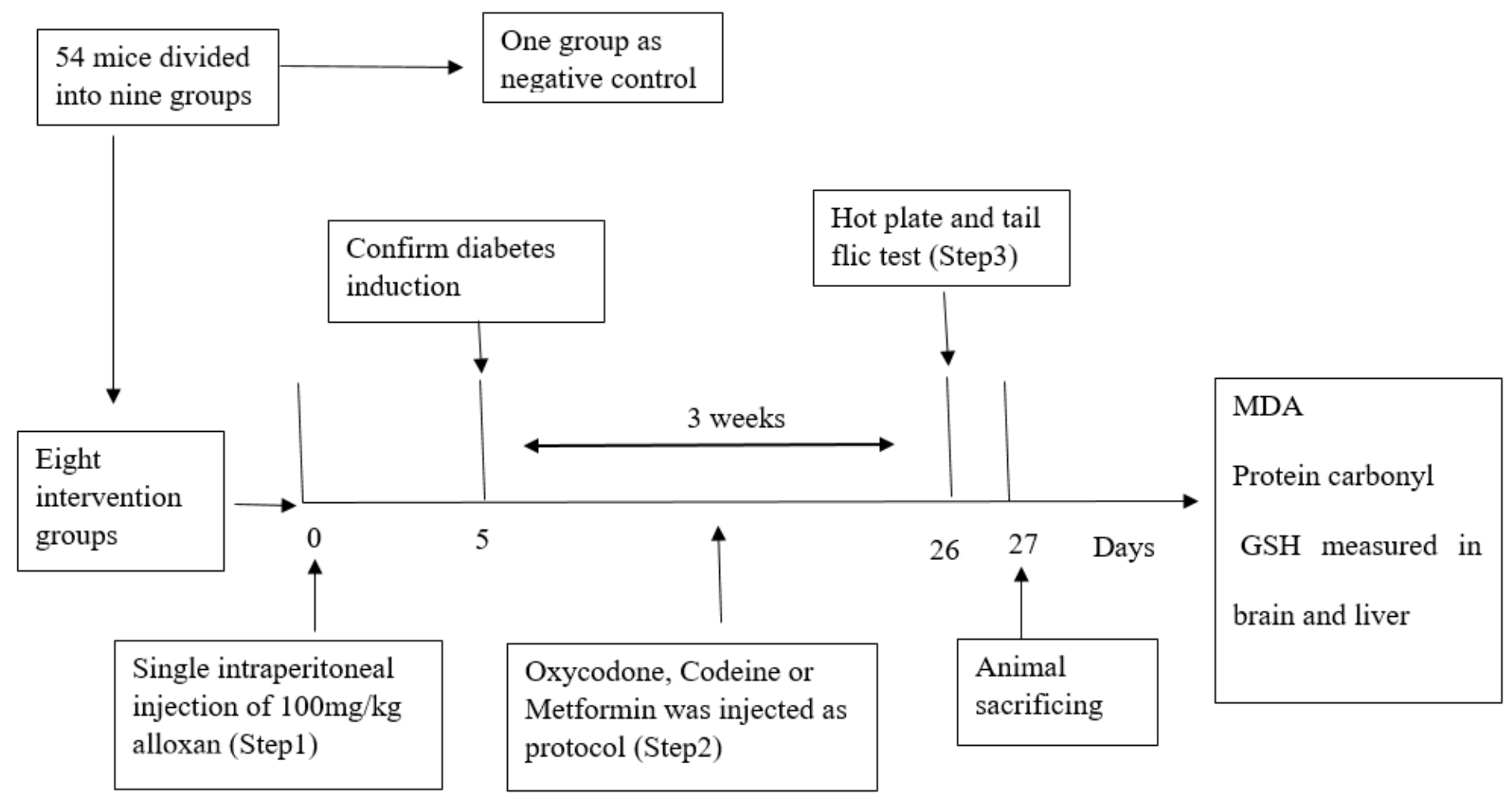

\section{Figure 1}

Schematic description of the experiment protocol 
bbb,ccc, ddd

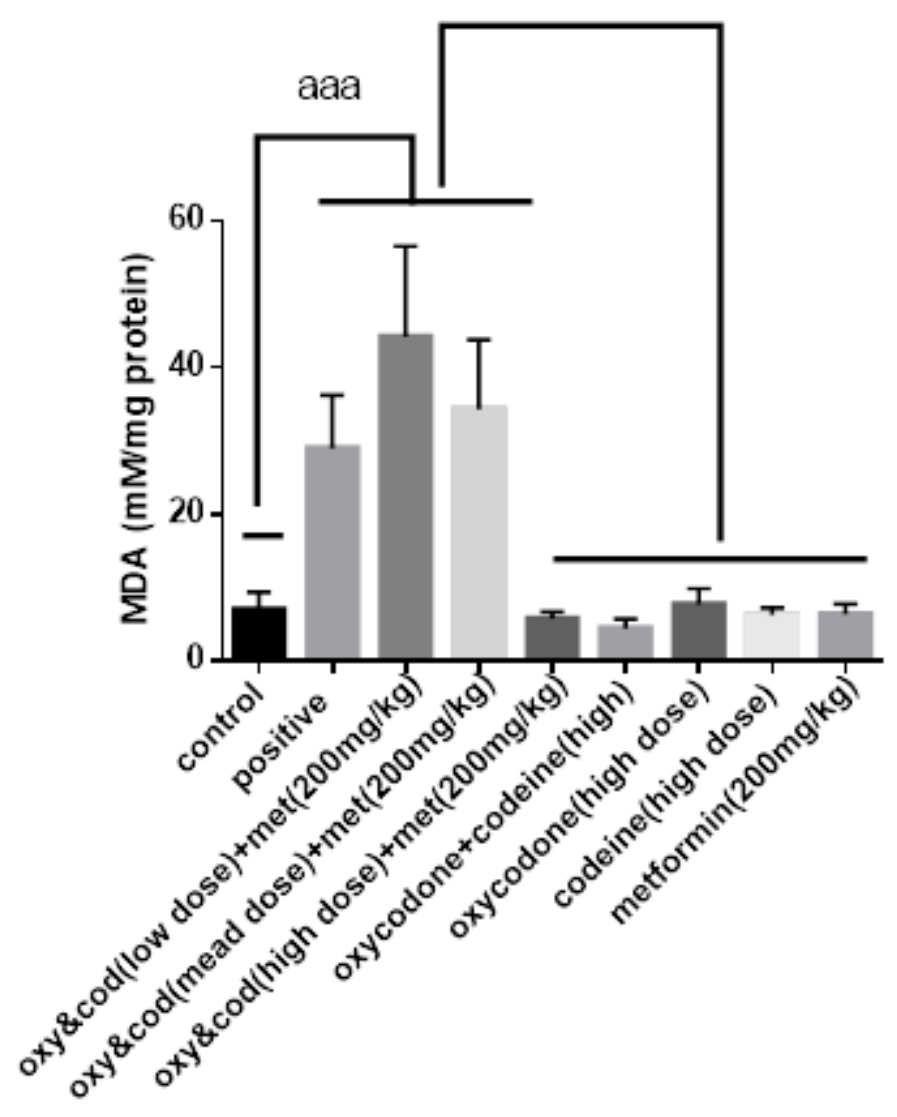

Figure 2

Combination effect of oxycodone, codeine and metformin on MDA content in mice brain mitochondria after 3 weeks treatment. Mean \pm SD $(n=6)$. aaa $p<0.001$ compare control group with oxy \&cod(low, mead, high)+met groups. bbb $p<0.001$ compare positive group with other drug groups. ccc $p<0.001$ compare oxy \& cod(low dose) +met with other drug groups. ddd $p<0.001$ compare oxy \&cod(mead dose) +met with other drug 


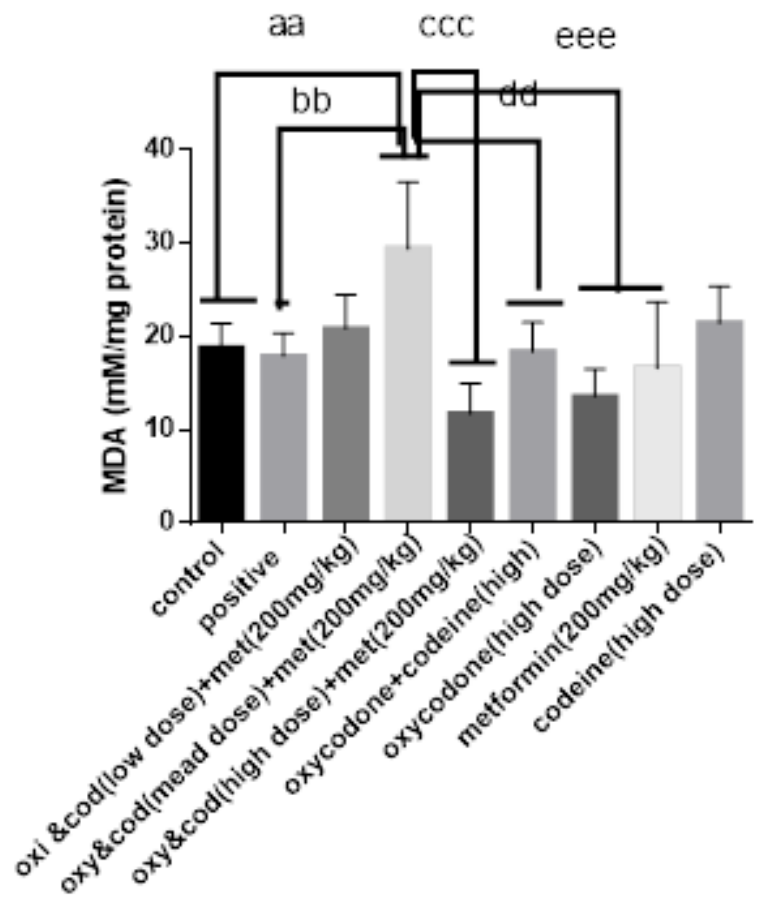

Figure 3

Combination effect of oxycodone, codeine and metformin on MDA content in mice liver mitochondria after 3 weeks treatment. Mean \pm SD $(n=6)$. aa $p<0.01$ compare control with oxy \&cod(mead dose)+met .bb $p<0.01$ compare positive group with oxy \& cod(mead dose)+met. ccc $p<0.001$ compare oxy \&cod(high dose)+met with oxy \&cod(mead dose)+met .dd $p<0.01$ compare oxy \&cod(mead dose)+met and oxycodone +codeine(high).eee $p<0.001$ compare oxy \&cod(mead dose)+met with oxycodone(high dose) and metformin $(200 \mathrm{mg} / \mathrm{kg})$. 


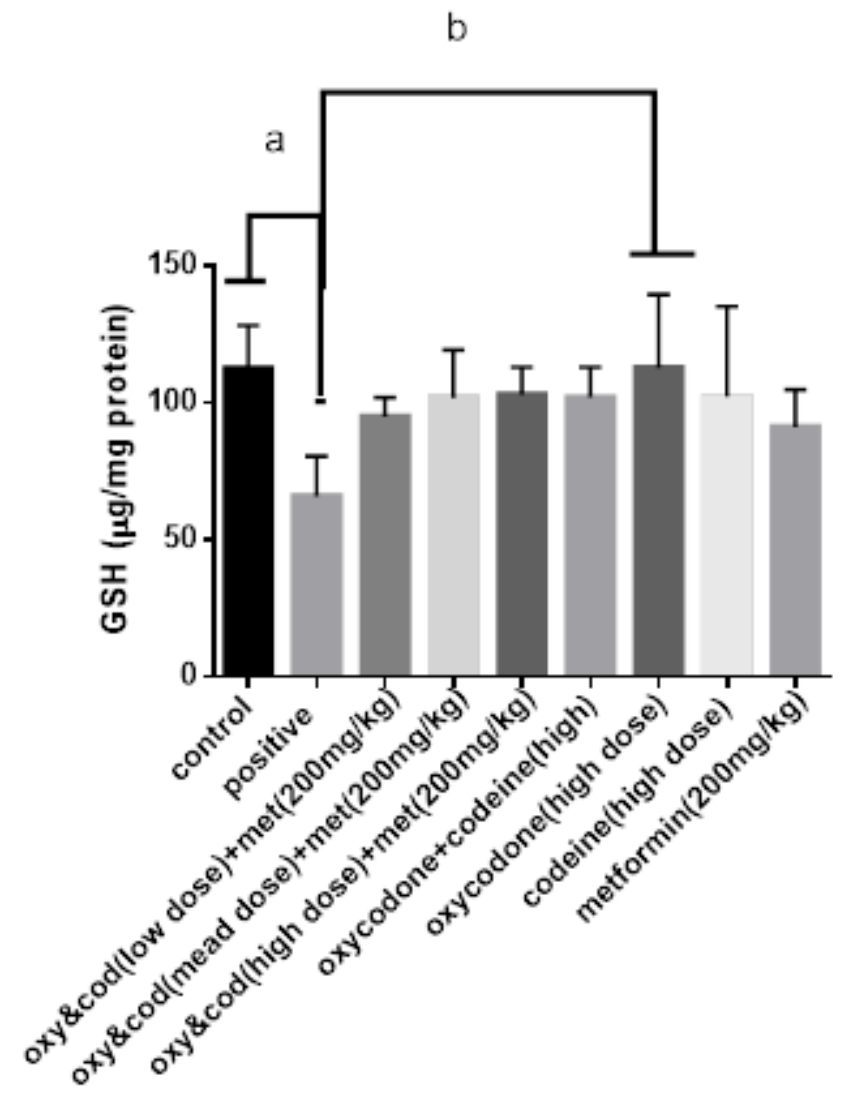

Figure 4

Combination effect of oxycodone, codeine and metformin on glutathione content in mice brain mitochondria after 3 weeks treatment. Mean $\pm S D(n=6)$. a $p<0.05$ compare control group with positive group. b p $<0.05$ compare positive group with oxycodone(high dose). 


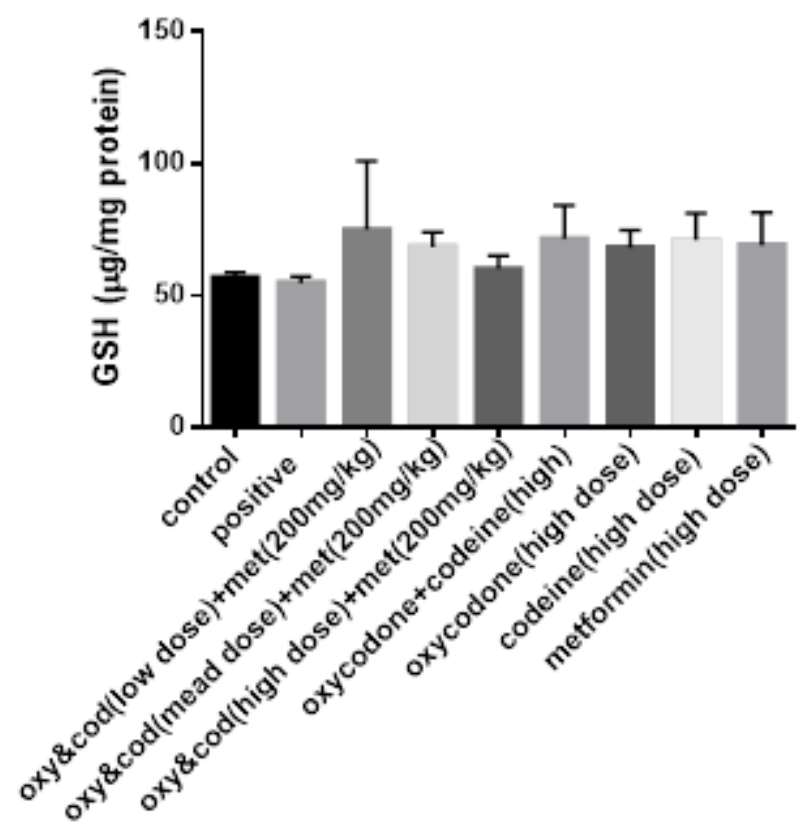

Figure 5

Combination effect of oxycodone, codeine and metformin on glutathione content in mice liver mitochondria after 3 weeks treatment. Mean \pm SD $(n=6)$. 


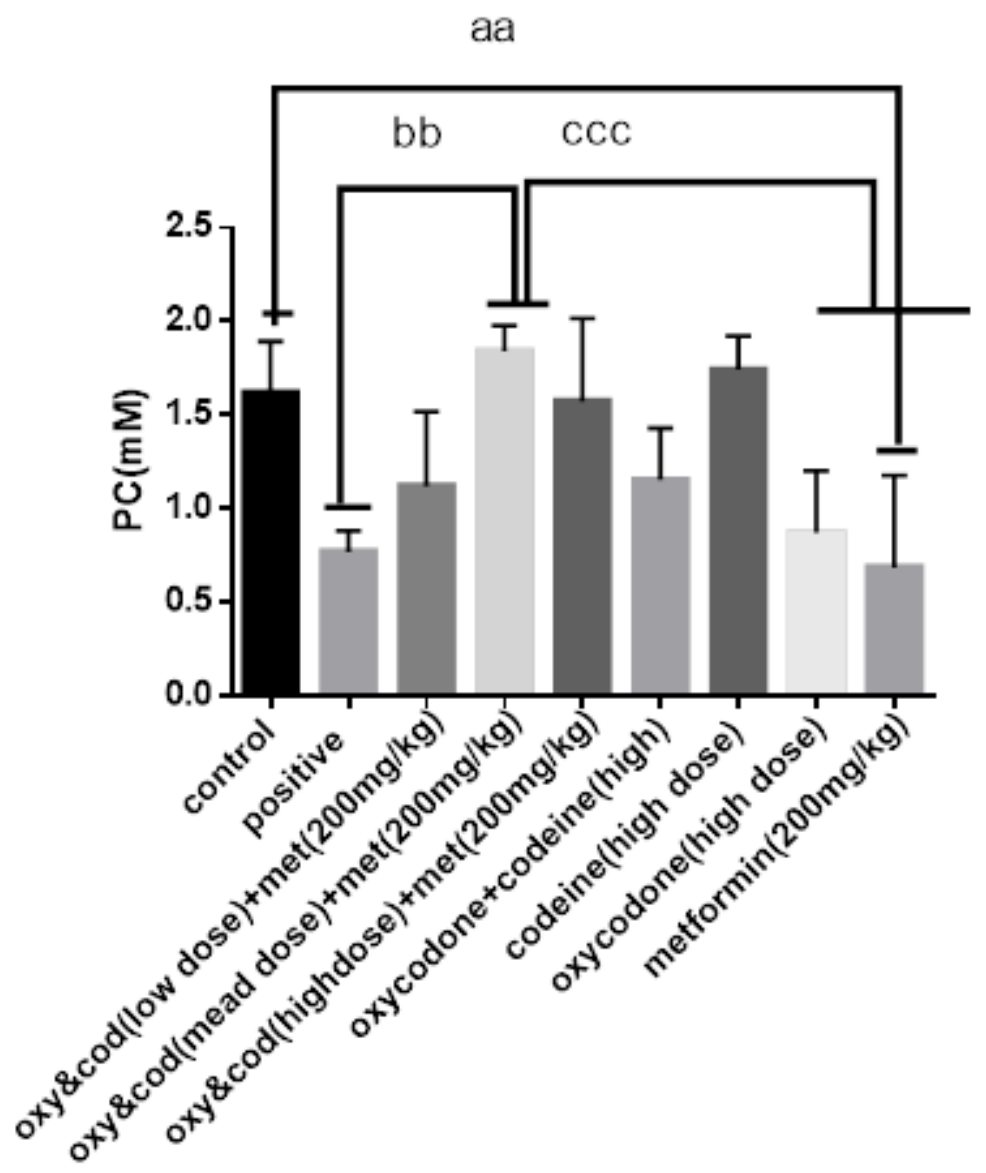

Figure 6

Combination effect of oxycodone, codeine and metformin on pc content in mice brain mitochondria after 3 weeks treatment. Mean \pm SD $(n=6)$ aa $p<0.01$ compare control with metformin $(200 \mathrm{mg} / \mathrm{kg}) \cdot \mathrm{bb} p<0.01$ compare positive with oxy \& $\operatorname{cod}(\operatorname{mead}$ dose)+met. ccc $p<0.001$ compare oxy \& $\operatorname{cod}(\operatorname{mead}$ dose)+met with oxycodone(high dose) and metformin $(200 \mathrm{mg} / \mathrm{kg}$ ).dd p $<0.01$ compare oxy \&cod(high dose)+met with metformin(200mgkg).e p $<0.05$ compare oxycodone(high dose) with codeine(high dose). 


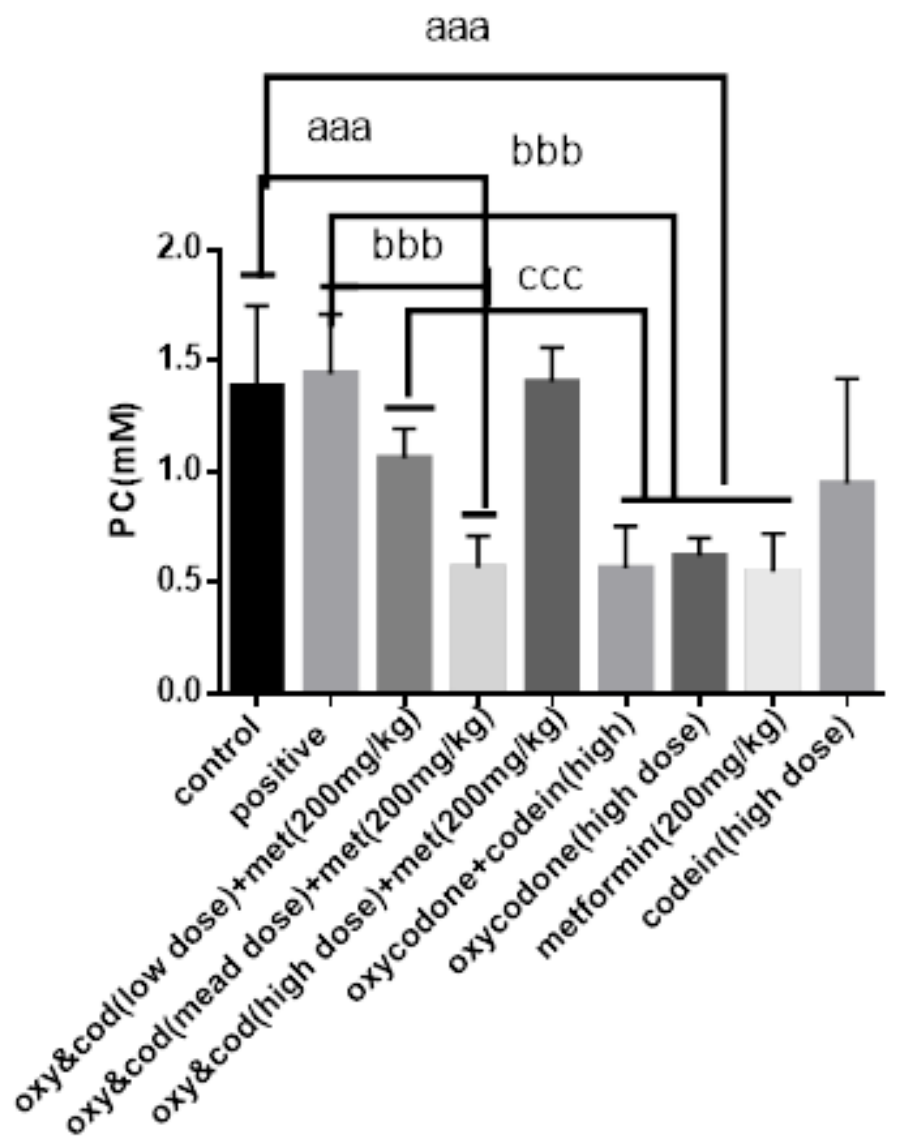

Figure 7

Combination effect of oxycodone, codeine and metformin on pc content in mice liver mitochondria after 3 weeks treatment. Mean \pm SD $(n=6)$. aaa $p<0.001$ compare control with oxy \&cod(mead dose) + met , oxycodone +codeine(high dose), oxycodone (high dose) and metformin(200mg/kg).bbb $p<0.001$ compare positive group with oxy \&cod(mead dose)+met . bbb $p<0.001$ compare positive group with oxycodone +codeine(high dose), oxycodone(high dose)and metformin(200mg/kg).ccc $p<0.001$ compare oxy \&cod(low dose)+met, oxycodone +codeine(high dose), oxycodone(high dose)and $\operatorname{metformin}(200 \mathrm{mg} / \mathrm{kg})$. 


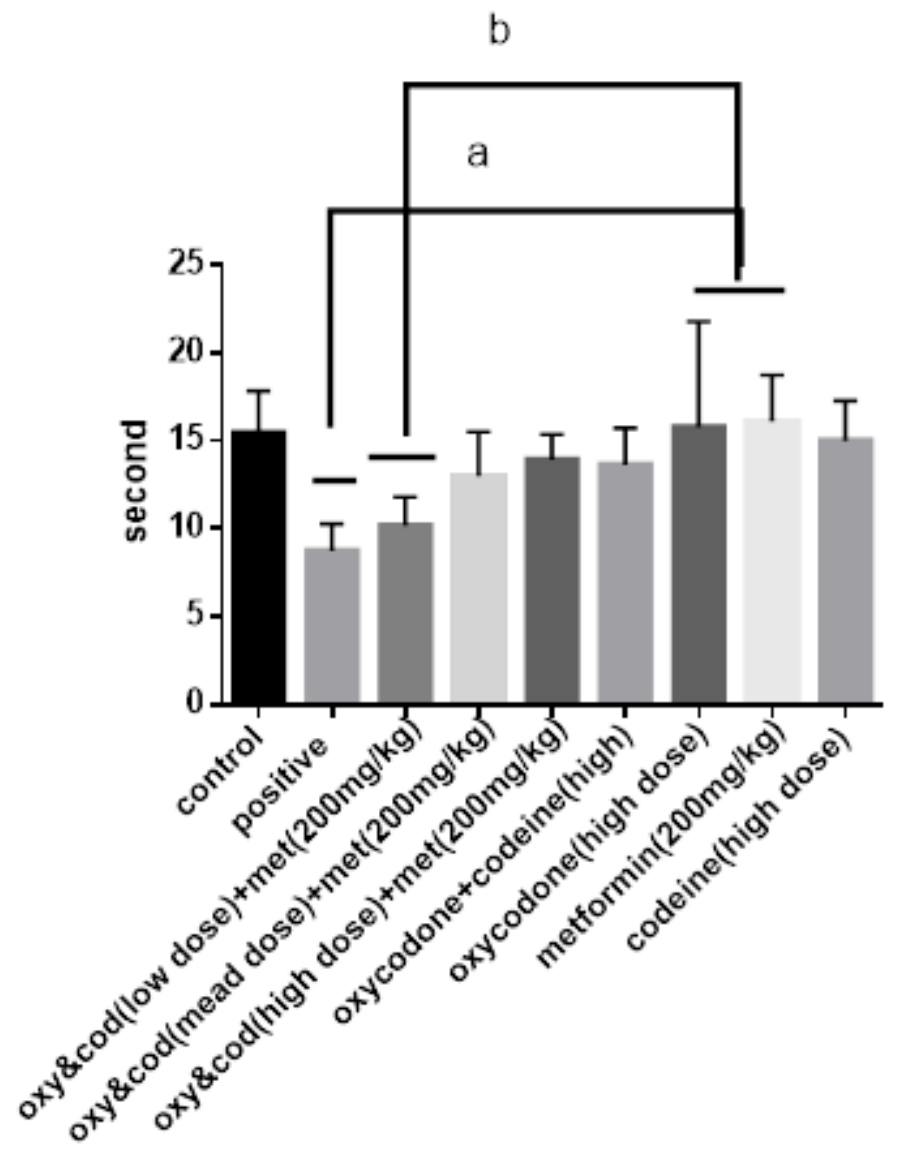

Figure 8

Combination effect of oxycodone, codeine and metformin on latency time of hot plate test in mice after 3 weeks treatment. Mean \pm SD $(n=6)$.a $p<0.05$ compare positive group with oxycodone (high dose) and metformin(200mg/kg).b p <0.05 compare oxy \&cod(low dose)+met with oxycodone(high dose)and $\operatorname{metformin}(200 \mathrm{mg} / \mathrm{kg})$. 


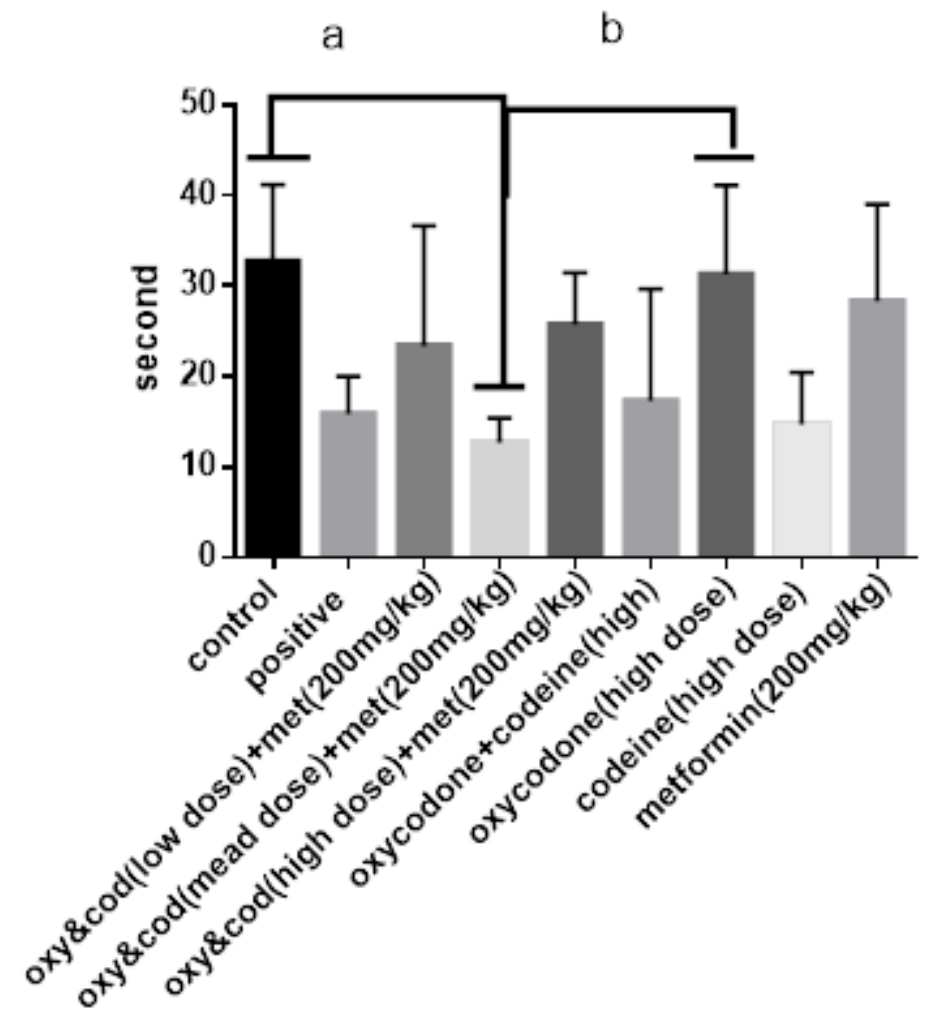

Figure 9

Combination effect of oxycodone, codeine and metformin on latency time of tail flick test in mice after 3 weeks treatment. Mean $\pm S D(n=6)$. a $p<0.05$ compare control with oxy \&cod(mead dose)+met. b $p<0.05$ compare oxy \&cod(mead dose)+met with oxycodone(high dose) . 


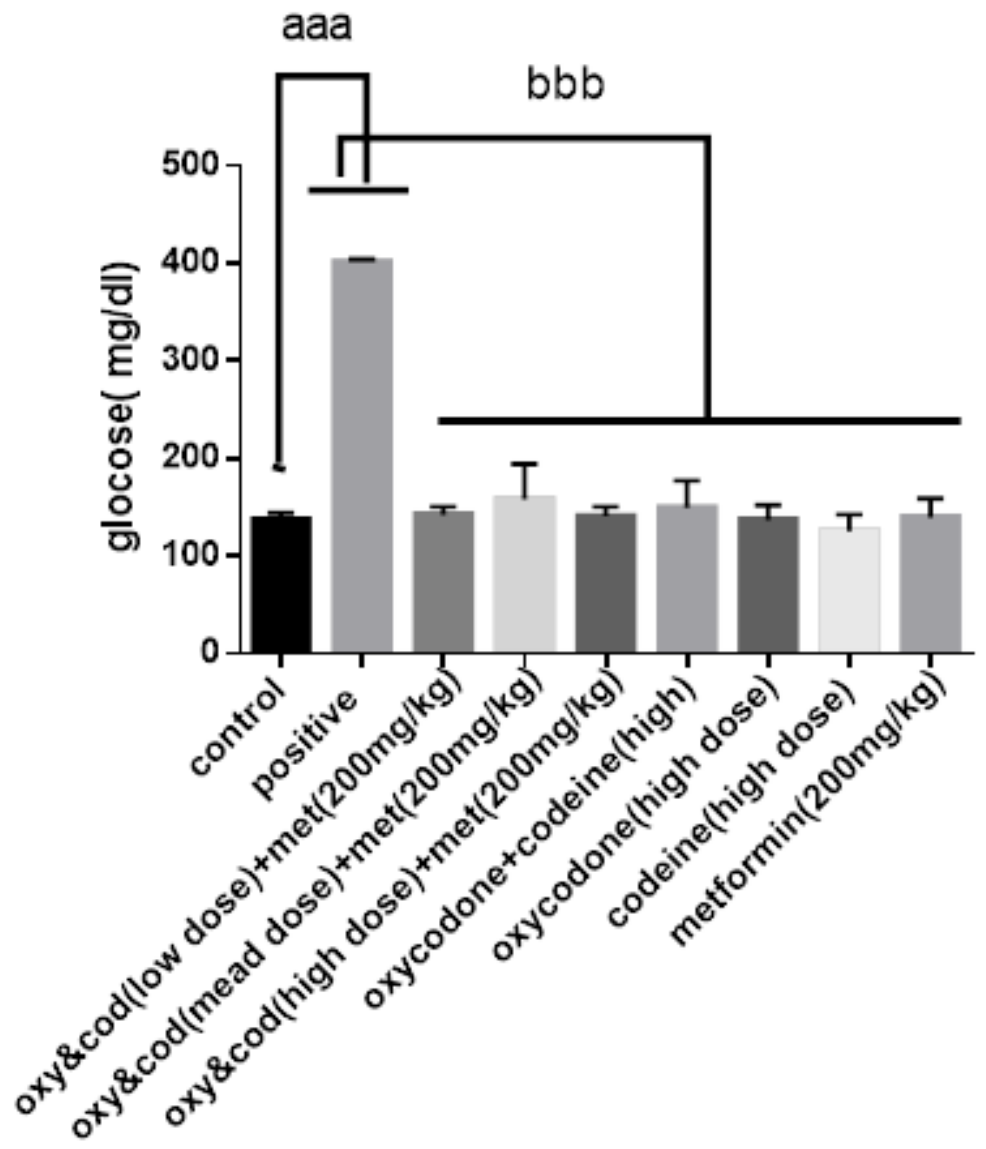

Figure 10

Combination effect of oxycodone, codeine and metformin on fasting blood glucose level in mice after 3 weeks treatment. Mean \pm SD $(n=6)$. aaa $p<0.001$ compare control group with positive(diabetic) group. bbb $p<0.0 .001$ compare positive group with all drug groups. 